\title{
Henry Neville's The Isle of Pines and the Emergence of Racial and Colonial Discourses in the Genre of Utopia in Britain
}

\author{
Zahra Jannessari Ladani \\ The University of Isfahan, Isfahan, Islamic Republic of Iran \\ E-mail address: z.jannessari@fgn.ui.ac.ir
}

\begin{abstract}
ABTRACT
This essay will explicate and study Henry Neville's The Isle of Pines as one of the most popular utopian/dystopian accounts written in the pamphleteering tradition current in the seventeenth century. The researcher will see how Neville's socio-political philosophy was molded in the highly turbulent atmosphere of the seventeenth century. Then, The Isle of Pines will closely be analyzed to assess its formation under the influence of the controversial nature of the politics of the time. We will also elaborate on Neville's introduction of the pamphleteering tradition to utopian fiction. In addition, Neville's employment and foregrounding of racial and colonial intentions will be discussed to see how these modern discourses gave shape and directed the genre of British utopia as an apology for the republic and commonwealth as the requirement of an age with a disturbed political face.
\end{abstract}

Keywords: Henry Neville; The Isle of Pines; seventeenth-century; utopia; pamphleteering; racial discourse; colonial discourse

\section{INTRODUCTION}

Henry Neville (1620-94), a seventeenth-century leading but now obscure British utopist, incorporated a number of discourses to the domain of British utopian fiction. Neville's utopian or, as critics have alternatively claimed, dystopian perspective considered the possibilities of addressing political, racial, and colonial debates of the time through new utopian forms and techniques postulated by the political and cultural requisites of seventeenth-century England and, more broadly, Europe.

A writer of polemical pamphlets, Neville produced a number of short works satirizing and disavowing the status quo. Such pamphlets, including The Isle of Pines, proposed new perspectives, adopted critical outlooks, thus building new worlds and populating them. The text's colonial ambitions, its implicit critique of absolute monarchy and propagation of a Nevillesque type of republicanism, and its racial overtones proffer new constructs and the ensuing sense of wonder to both audiences of its time and later. This essay will examine the new discourses Neville introduced into British utopian literature based on his historical and political backdrop. 


\section{DISCUSSION}

\section{1. Henry Neville, Politician and Writer}

Neville lived in an extremely politically disruptive and revolutionary time, being witness to both the ascension and the demise of several British kings and lord protectors: the last five years of James I.'s monarchy, the sovereignty of Charles I. (1625-49), the Protectorate of Oliver Cromwell (1649-60) and his son, the Restoration of Charles II. (1660-85), the short rule of James II., his deposition in the Glorious Revolution of 1688, and the accession of Mary and William of Orange.

Three years after Charles I. came to the throne, the Stuart King became involved in a number of military expeditions against Spain and France for the heavy expenses of which he asked Parliament to vote for taxes. Disobeyed, however, Charles dismissed Parliament and collected taxes under duress. In 1628, Constitutional crisis reached its climax, so Parliament passed the Petition of Right to which Charles assented quite reluctantly. This merely exacerbated the relationship between the King and the House of Commons. The quarrels between the King and Parliament, the bloodshed of the Civil War, in general, and the two Bishops' Wars against the Scotts, in particular, led to Charles I.'s defeat by the New Model Army of Oliver Cromwell and his execution by English republican revolutionaries.

Four years before the decapitation of the King, Neville returned to England in 1645, launched his long political career in Parliament, sat on the 'Goldsmith's Hall committee on delinquents' in 1649, and served on the 'Council of State' in 1651 while still being Oliver Cromwell's favorite (Hardy 5). After the execution of Charles I., a republican form of government, known as the 'Commonwealth,' was established, and monarchy and the House of Lords were abolished.

Neville's perception of the tempestuous Monarch-Parliament relationship and the dominant patriarchalism of his time led him to write coarse lampoons before and after the execution of Charles I.: A Parliament of Ladies with Their Laws Newly Enacted (1647), The Ladies, A Second Time, Assembled in Parliament (1647), and News from the New Exchange (1650) (Mahlberg 7-8). The first two pamphlets, libels on a women's disobedient parliament, satirized the patriarchal absolutism of English monarchy, particularly targeting Sir Robert Filmer's Patriarcha or a Defence of the Natural Power of Kings Against Unnatural Liberty of the People (1680) (115-16). The latter, however, critiqued the new Commonwealth government's avarice and lust for power.

In the post-regicide socio-political mélange, the Model Army and Parliament, both in charge of the nation, were constantly quarrelling together, thus becoming extremely unpopular. Heavy taxes and religious disputes continued to be a major problem for the nation. The national church had grown excessively Puritanical under the direction of the majority in Parliament, and frequent modifications in the form of government would not remedy the diseased body of England. In 1653, Oliver Cromwell, the commander of the Army and formerly an influential Member of Parliament, forgot 'the good old cause,' dissolved Parliament, and turned Lord Protector, essentially becoming identical to a king. Cromwell's notorious Protectorate came to an end when he died in 1658, and his son, Richard, succeeded him. Neville's anti-Cromwellian tract, Shuffling, Cutting, and Dealing in a Game of Piquet (1654), belonged to this period and caused his abdication from London for four years (Ford 33).

Richard Cromwell became Lord Protector after his father's death, but not equal to his newly inherited title, he was overthrown by Parliament members who reassembled and recalled Charles I.'s son, Charles II. (1630-85), then in exile, to throne. Having gone through the failure 
of republicanism, or more precisely anarchism, the nation drifted back toward the traditional royal government through the 1660 Restoration.

With the Restoration of Charles II., Neville's dream of a commonwealth melted away. Back in England during his banishment, Neville was imprisoned in the Tower for his suspected role in the Yorkshire uprising, but he was released due to lack of evidence against him after fourteen months (Robbins vii). Neville's arduous political life, nevertheless, did not impede his writing career, but rather led him to adopt a more conservative tone, such as in The Isle of Pines (1668), which was written during his post-exile and post-incarceration period. This brief pamphlet, anticipatory of the 'flat objectivity of Robinson Crusoe and Gulliver's Travels', rendered Neville's philosophical view of 'man's natural ability to create both a population and an organized Christian society on a desert island' (Sherburn and Bond 797).

Neville's Plato Redivivus, or A Dialogue Concerning Government (1742), his next conservative and final work, was a vain plea to Charles II. to discern that his glory and survival were guaranteed solely through a voluntary reduction of his prerogatives and powers (Worden 458). Neville, an active member of the 'Rota Club' - founded by James Harrington, and later a fashionable center for the discussion of Harrington's political ideas (Hill 191) - drew on Harringtonian principles of Oceana (1656) to formulate his own political thesis in Plato Redivivus. While Harrington was a full-fledged advocate of democracy, Neville recognized that the best solution to the political chaos of the time was the reforming of the English monarchical system, i.e. the formation of republicanism under monarchy (Sullivan 181). Like Bacon, Neville spent a politically dejected retirement and continued his scholarly career focusing on a series of translations including Machiavelli's The Prince and The History of Florence before fading into obscurity.

\section{2. The Isle of Pines}

The Isle of Pines (1668), Neville's fifth publication, deploys the frame narrative and the epistolary form to render the story of an unknown island discovered twice. W. C. Ford's edition of The Isle of Pines includes two letters at the beginning of the main story written by a fictional Abraham Keek addressing a 'credible person in Covent Garden' on 19 June and 6 July 1668. The former breaks the news of a ship whose commander related that somewhere near 'Cape Finis Terre,' they 'fell in with an island' inhabited by nearly two thousand naked Englishspeaking people who had touched shore a hundred years back, having no access to other parts of the world and other nations (Neville, The Isle of Pines 53). The second letter promises more information in future.

The main story, however, is recounted by the Dutch commander of the ship, Henry Cornelius Van Sloetten who declares the truth of his voyage to and the discovery of an island near the Coast of Terra Australis Incognita. Van Sloetten's epistle is an attempt to render a precise and detailed account of the expedition in the terms of a 'Seaman' rather than a 'Schollar' (55). The voyage begins on 26 April 1667, a year before the publication of the text of the Isle of Pines, when the ship sets sail from Amsterdam for the East Indies. After anchoring at several ports, such as 'St. James's' in 'Cape Verd' and 'St. Laurence' in 'Madagascar', for victuals and business, the trade ship encounters a violent storm for a fortnight which pushes the vessel far back and claims the life of some of the travelers.

Experiencing alternatively favorable and violent winds, the ship eventually inspects a curious island on the shores of which people run 'promiscuously.' The initial words Neville's sailors address, in Dutch, to the Pineans are 'Wat Eylant is Dit?' (57). The Dutch eventually succeed in communicating with the English-speaking islanders through Jeremiah Hanzen who 
speaks English very well. The naked islanders flock about the travelers, struck at the sight of their ship and clothes, as if bewildered by a miracle.

The islanders welcome their guests and provide them with both familiar and strange nourishments peculiar to the Isle of Pines. They are, then, taken to the island's chief Ruler, William Pine who is George's grandson, and his half-naked wife and maids. Surprised at Pineans' primitive culture, the Dutch facilitate them with knives, axes and hatchets. In return, Prince William invites the Dutch to his humble palace and, in response to Jeremiah's query about Pineans' origins, reads a tract in George Pine's hand, a copy of an autobiographical relation of the first men touching the shore of the island.

Shifting from William to George as the narrator, the story reveals an old narration written a hundred years ago. A group of people including an English merchant, his wife and children, his bookkeeper (George Pine), and his maidservants embark on a commercial expedition to India licensed by Queen Elizabeth in 1569. Past the Canaries, Cape Verd, St. Hellen, and St. Laurence, the ship is taken to a very rocky piece of land and wrecked through strong storms. Some of the crew perish in an unsuccessful attempt to escape in the long boat, others are drowned while swimming to the island. Only one man and four women survive and set foot on the land: the merchant's bookkeeper, daughter, maidservants, and black slave.

The survivors find the island safe and lush, a real idyllic niche: 'this place (had it the culture, that skilful people might bestow on it) would prove a Paradise' (66). Thus, they fall into an idle and libertine life, engaging in open polygamy and interracial copulation. George Pine, the only man on the island, impregnates all of the females. Pine and his women's sexual activity turns into a vigorous childbearing and populating project so much so that within fifty years the island is peopled with one thousand seven hundred and eighty nine individuals.

Keeping an exact account of his progeny after a fruitful half-century's time, George Pine, the professional bookkeeper, administers their christening, giving the surname of each wife to her offspring, thus organizing the social structure of the island in tribal terms: the English (after Sarah English, the merchant's daughter), the Sparks and the Trevors (after Mary Sparkes and Elizabeth Trevor, the two maidservants) and the Phills (after Philippa, the Negro slave bearing no surname). He also authoritatively arranges marriages to forestall incest and adultery: 'I took off the Males of one Family, and married them to the Females of another, not letting any to marry their sisters, as we did formerly out of necessity' (69). Further, having undertaken to establish an obligatory monthly Bible-reading meeting, George Pine constitutes a patrilineal inheritance system by means of which he nominates his eldest son, Henry, 'King and Governor' (70), a venue quite reminiscent of Bacon's 'feast of the family' in the New Atlantis.

At this juncture, George Pine's narration comes to an end and Van Sloetten's relation of William resumes. William narrates the unwritten story of his father, Henry (George and Mary Sparkes's son), whose rule initiates at a time when the multitude under him, tied by no firm religious bonds and enjoying the island's lushness, gradually deteriorates into utter 'whoredoms, incests, and adulteries' (72). To redress enormities, Henry fortifies the jurisprudence of the island by declaring the wrong done by the delinquents in an assembly of 'the Company near unto him' who unanimously vote for severe punitive measures against such criminal cases (72). Therefore, John Phill, second son to the Negro woman and proved guilty of ravishment and tyranny, is executed by being thrown down from a 'high Rock into the Sea' (72). Soon after, Henry sets forth the first mosaic legislative manifesto - six draconian laws concerning blasphemy, rape, adultery, rights of the neighbors, reading of the Bible, and obedience to the Governor - which effectively solves the problem. Here, William concludes the story of Henry's reign. 
The next day, the Dutch traders participate in the Pineans' monthly assembly of 'Religious Exercises' where several weddings are conducted by the priest with the consent of the couple's family or relations, and then people attentively listen to the Word of God and abstain from 'all manner of playing and pastimes' (75). A tour of the island reveals to the Dutch the acculturation of a generation of the English people from civilization back to primitive life caused by their long insulation in an inaccessible environment. The nude Pineans dwell in handmade huts, drink water instead of liquor, flea at the racket of a musket, take the Dutch's bagpipe for an animal and, not equipped with tools of any kind to dig graves, they cover the corpses of their dead with enough stones to keep them from beasts and birds. But lack of technology has made nimble dancers and adept vocalizers of the Pineans.

The Dutch decide to build a 'Lordly' - actually a humble one compared to those in Europe - palace for William Pine, using their 'cutting Instruments' to fell the trees. On leaving the island, the Dutch hear of a nascent insurrection reported by William who implores their assistance. This time, having ravished the wife of one of the chiefs of the Trevors, Henry Phill, the ruler of the Phills tribe, induces a threatening 'hurly burly' and 'general ruin to the whole State' (80). William's interposition is of no avail for his authority is too weak to repress the disorders, but the armed Dutch prevail, and Henry Phill is executed.

Setting sail, the Dutch head for India where they visit the mysterious metropolis of Calcutta and its 'Brachmans' (82). 'Brachmans' serve as breeders to the Indian Monarch's sisters whose offspring will be future sovereigns due to the warranted Royal blood circulating in their veins. Contrary to the primitive Pineans, the Indians are civilized people highly conscious of their caste, performing indigenous customs strange to the Dutch like adorning themselves with jewels and other ornaments befitting their social rank. Finally, the Dutch head for their homeland after trading with Indians.

\section{3. The Isle of Pins, Pamphleteering and Republicanism}

Despite its obscurity in our time, the Isle of Pines was one of the most popular and successful tracts in Neville's England and Europe (Aldridge 464). The Isle of Pines is braced within a very complex structure: the baroque structure of the text makes copious use of the frame narrative and the epistolary form conflated with the pamphleteering tradition of seventeenth-century prose writers. During the seventeenth century, pamphleteering became widespread as pamphlets could be inexpensively published and circulated among different social echelons due to literacy augmentation.

Pamphlets were small books with no jacket covers, employing racy title pages, usually carrying shocking or violent titles to impress more readers - purchasers. Functioning like 'our own contemporary tabloid papers,' seventeenth-century pamphlets recorded 'trials, bloody crimes, and the subsequent graphic executions of condemned criminals' as extremely popular topics. For instance, the 27-June-1668 version of The Isle of Pines included a frontispiece with four pictorial panels depicting momentous occasions in the narrative (Hardy 16-17).

Most seventeenth-century pamphlets were 'hoax' stories avidly read, enjoyed, and frequently believed by people. Under pseudonyms, most pamphleteers were not concerned with fame as much as with survival and profit. Moreover, the form was very apt for the distribution of dissident ideas voiced by underground political polemicists and thinkers in seventeenthcentury Britain. Neville, a specialist in the art of pamphleteering, deployed the utilitarian literary form to work out his reformist political theses, and criticize the status quo. As a result, he resorted to rhetorical devices of persuasion to blur the boundary between the real and the 
fictional. The two letters at the beginning of Ford's edition of The Isle of Pines serve this purpose, the first of which comes below:

Amsterdam, July the $6^{\text {th }} 1668$.

It is said that the ship that discovered the Island, of which I hinted to you in my last, is departed from Rochel, on her way to Zealand, several persons here have writ thither to enquire for the said Vessel, to know the truth of this business. I was promised a Copy of the Letter that came from France, advising the discovery of the Island above-said, but it's not yet come to my hand; when it cometh, or any further news about this Island, I shall acquaint you with it,

Your Friend and Brother,

A. Keek (Neville, The Isle of Pines 53-4)

In the story, George Pine commands his successors to deliver a 'Copy' of his 'Narration' to prospective travelers visiting the island so that the Pineans' 'name be not lost from off the earth' (70). The two letters, printed after the publication of the mysterious pamphlet written a century back by a 'George Pine' but newly discovered and accessible to the public, created a great sensation among people. In The Isle of Pines: An Essay in Bibliography (1920), Ford enumerates several foreign editions of the text: Dutch, Italian, French, German, and American which demonstrate the prompt welcome Neville's text received across the Continent and elsewhere.

In Neville's the Isle of Pines, George Pine's tract is treated as a relic from the past; thus, the island is publicized in both oral and written forms. Compared with Neville's utopia, there is no written tract in either Bacon's New Atlantis or More's Utopia. This, in its own right, hints at the emergence of a seventeenth-century sub-literate and socio-politically conscious public who enthusiastically interacted with the print culture of the time, and actively participated in coffee-house talks on the hot debates of the day. This latter was a new phenomenon in the Restoration and affected Neville's writings. P. G. Stillman argues that, having in mind coffeehouse talks and imagining participants' active discussion of his text, Neville avoided univocal meanings and kept open some issues within the confines of the story (169).

In the Isle of Pines, one moves through a narrative maze consistent of polyphonic voices: the story, excluding the letters not published as part of the original tract, starts with Van Sloetten's letter, moves back to William Pine, dives down to a century-old autobiographical tract with George Pine's voice, returns to William's account, and finally resurfaces to the first narrator, Van Sloetten. This multifaceted but delicate play on the readers occurs on both horizontal and vertical dimensions regarding the motifs of shipwreck and immersion before the survivors shore. Resembling a dive into the depth of time and a return to the present, thus bridging two historical junctures, the narrative movement of the Isle of Pines echoes J. Mangold's Kate and Leopold (2001) and H. G. Wells's The Time Machine (1895) to some extent. Time travel and a jump into new and old worlds are thus achieved simply through Neville's adroit frame technique, rhetorical devices of persuasion, and the epistolary form.

Besides being a pamphlet, the Isle of Pines also heavily draws on utopian elements and travel writing. The author's environmental descriptions convey an ideal niche at the heart of the ocean: a free land with no indigenes, blessed with an ample and human-friendly ecosystem. On the Isle of Pines, there is no need for labor of 'husbandry' or 'defence' whereas Bacon's Bensalemites and More's Utopians have to engage themselves in crafts and arts of diverse sorts, as demanded by their institutes, to survive (Bruce xxxix). The climate of the Isle of Pines is so moderate that Pineans need no clothes, the fauna so tame that they need not go hunting. The utopian aspect of the island is not only acknowledged by the Pineans but also by the Dutch 
merchants who might have done traffic with the Pineans, had the Pineans the culture and spirit to exploit the natural resources of the island to build a more advanced civilization. But the fascinating point about the Isle of Pines is that it is precisely the virginity of the locus that makes it a paradise.

The liberal, and later libertine, condition in which the initial George Pine and his consorts live seems even more paradisiacal, a state of affairs exempt from laws or restrictions (Hughes viii). But troubles emerge as soon as tribal divisions, and subsequently sexual taboos, are introduced by the later George Pine, Henry's Mosaic laws and his execution of John Phill, and William and the Dutch's corporate execution of Henry Phill. Thus, utopian anarchy is replaced with chaos when George's inefficient patriarchy is reformed, by his son and grandson, through the gradual establishment of 'legal strictures to protect' individuals and 'property' in a 'neoAdamic settlement' (Wiseman 149).

Given that Neville was an adept pamphleteer and satirist, one can detect that he was, indeed, representing the growth of corruption in the process of the British historico-political evolution. Neville's implicit and explicit erotic references throughout the text addressed the lasciviousness of British monarchs, particularly Charles II., who claimed more prerogatives by draining and debilitating their subjects. An increase in the Monarch's prerogatives combined with the royalist maxim that the King drew his 'power immediately from God' and was 'accountable to God alone' for his actions was unpalatable to the rationalist, secular, and republican Neville (Sommerville 349 and 361).

Contrary to Thomas Hobbes (1588-1679), Neville and his like-minded compatriots, including James Harrington, thought that the breakdown of political institutions between 1640 and 1660 signaled a call for a more profound re-examination of and reform in political beliefs and practice (Worden 443). Frustrated by twenty years of Civil War, Neville proposed his conservative thesis for Government: instead of attempting to wrest power from the King, Parliament should gain more rights by 'humbly remonstrating to his majesty, that it is his own interest, preservation, quiet and true greatness, to put an end to the distractions of his subjects' (Neville, Plato Redivivus 234). Neville advised that four Parliament councils, annually changed to avoid compromise and seduction, control and limit the administration of the crown in different executive branches (253-54).

Although Neville's propositions did not exactly represent republicanism, they heralded a 'republican tradition' which later penetrated the political mainstream of eighteenth-century Britain, Europe and America (Worden 91). Neville and other republicans' utopian views were first materialized not in England, but in the American colonies newly weaned from the old mother through the Declaration of Independence on 4 July 1776. The Isle of Pines, with its painstaking movement from monarchy to republicanism, is nothing like Bacon's strictly hierarchical and monarchical New Atlantis; neither is it similar to More's Utopia, an advanced and organized commonwealth. The Isle of Pines remains republicanism in the making. The examination of the possibility of British republicanism in the immediate historical context of Neville's time, with so close and realistic a scrutiny of the origins, is a task neither More nor Bacon succeeded in achieving in their own time. Put it differently, Neville's utopian perspective neither takes a sublime form nor is it consecrated by the author whose satirical treatment of the subject subverts its utopian overtones. As a result, The Isle of Pines has also been interpreted as a dystopia (Boesky 180-81; Bruce xl). 


\section{4. Neville and the Examination of Colonialism and Racialism in Utopia}

In addition to incorporating the political discourse of republicanism into the genre of utopia in Britain from both philosophical and aesthetic vantage points in unprecedented terms, Neville merged colonialism with racialism as new discourses in the Isle of Pines. One might contend that utopists such as More and Bacon, too, deployed colonial and racial motifs in their utopias, but one should bear in mind that Morean and Baconian utopians were not as much realistic as they were parabolic. That is why they both seem so idealistic. In Bacon's New Atlantis, travelers are submissive to the authorities of the new land, observing rather than colonizing it. In More's Utopia, we have Hytholday's detailed account of the ideal world he has visited, not the colonial report of a Christopher Columbus. The only colonial intentions left, in More's case, pertain to Utopia's warfare policies, and in Bacon's, to intelligence agencies and scientific institutions.

In Neville's case, however, there is a land discovered by George Pine and his companions for the first time, with the potential of being colonized. The island bestows all its treasure on the survivors and the only thing missing in this new world is 'labor.' This is what many critics have observed, but the point is that the islanders are by no means idling, because the island undergoes a sort of industrial revolution as soon as George Pine and his women start breeding, i.e. the island turns into a reproduction plantation.

Neville had perhaps read Bacon's advice on plantations: 'The people wherewith you plant ought to be gardeners, ploughmen, labourers, smiths, carpenters, joiners, fishermen, fowlers, with some few apothecaries, surgeons, cooks, and bakers' (Bacon 457). Without sufficient labor force, however, Bacon's advice would make no sense. On the Isle of Pines, man-as-labor-force is lacking in the first place. So Pine sets out to populate the void as laboriously as possible. Furthermore, Pine and his women seem to be competing with the other insular species: "we made use of ... a beast about the size of a Goat ... which brought two young ones at a time, and that twice a year' (Neville, The Isle of Pines 66).

So Neville's island, before being populated, is basically an ecological, not an anthropological utopia; hence, the fundamental difference between Neville's utopia and those of Bacon's and More's. But even from a Baconian point of view, the island can be conceived as a huge biological lab in which the conspecific codes of a newly added taxonomical group homo sapiens - can be examined. In this lab, George studies the genealogical features of his women and offspring:

The first brought me a brave Boy, my Master's Daughter was the youngest, she brought me a Girl, so did the other Maid, who being something fat sped worse at her labour: the Negro had no pain at all, brought me a fine white Girl ... (67)

Neville's concern with population turned into one of the basic themes of science fiction since the 1930s when pulp writers began to facilitate and support human life on other planets by terraforming or re-engineering them. These writers, too, had to populate new planets, if not new islands, the population of each planet inevitably undergoing acculturation based on the environmental gestalt of the place. A twentieth-century science-fiction writer notes:

What are we going to make of this planet? We can make it anything we want ... it's up to us. They say man is endlessly adaptable. I say on the contrary that man doesn't adapt himself as much as he adapts his environment. (Heinlein 194) 
Considering The Isle of Pines, one may say that Neville's Pineans both adapt themselves to the island and bring the island to adapt itself to them by exploiting its resources however primitively:

\begin{abstract}
by the help of an Ax and some other implements (for we had all necessaries, the working of the Sea, having cast up most of our goods) I cut down all the straight poles I could find, and which were enough for my purpose, by the help of my company (necessity being my Master) I digged holes in the earth setting my poles at an equal distance, and nailing the broken boards of the Caskes, Chests, and Cabins, and such like to them, making my door to Seaward ... (Neville, The Isle of Pines 65)
\end{abstract}

Thus being more than equipped with mere biotechnics, Neville's Pineans are Homo Fabers, making use of biological as well as non-biological tools to survive, their technics initially 'life-centered' rather than 'work-centered' (Mumford 7-9). But the land also works on the new inhabitants, thus metamorphosing them into brand-new indigenes. Their metamorphosis is obvious when the Dutch merchants first take sight of the naked bodies of these English-turned-aborigines running on the coast.

Pineans' metamorphosis corroborates Bhabha's 'mimicry' effect in the colonial discourse. Pineans are 'a reformed, recognizable Other, as a subject of difference that is almost the same, but not quite' (Bhabha 86). Although Pineans do not encounter any natives after the exploration of the island, they are still affected by the climate, environment, and even the fauna of the island so much so that George occasionally has to remind them of their British origins, trying to implant his native tradition within the minds of the new generation who has never seen its ancestors.

Besides the colonial infrastructure of the Isle of Pines including the Dutch's gaze at the New World, their commercial visit to India, and their language of commerce and calculation, Neville's text is the utopia of other races and societies, not simply one other race or society. As A. Boesky asserts, 'utopias prior to Neville's' were 'racially homogeneous.' But Neville 'illumines classifications' in his utopia which 'most mattered to him and to his culture, defining the English as antagonists of a race they used to identify themselves as masters' (Boesky 167). What is more, through George's union with the two maidservants and the Negro female slave, Neville's utopia 'complicates and eroticizes the relations between master and salve, embedding colonial politics within the structure of the patriarchal family.' This phenomenon had become part of the English culture from the 1660s-80s (170).

The Isle of Pines is a multi-racial text in which Neville includes both white and black, the Dutch, the East Indians (Brahmins), even Africans, though en passant. Neville employs a nonEnglish narrator, Van Slottoen, whose relationship with the Pineans is a microcosmic reflection of the real world at a time when the two nations were engaged in the Anglo-Dutch Trade War. The English fleet had been mauled badly by the naval prowess of the Netherlands. Nonetheless, Neville satirically portrayed the Dutch sailors as friends and benefactors of the English Pineans on different occasions, for instance, when the Dutch built William a palace, and when they resorted to arms to suppress the rebels (166).

Neville's Pineans, however, are not as kind to blacks as they are to the Dutch. The Isle of Pines contains numerous references to Negros as an inferior, bestial, corrupt and rebellious race. George Pine represents Philippa, the Negro slave, as the last object of sexual desire, the first woman to give up bearing children, and the first to die among the survivors. One may argue that Philippa died first, because she was put to hard work from the very beginning: when the 
survivors got on shore half-drowned, George Pine and the other three women prepared to sleep leaving Philippa outside the 'lodging,' because, supposedly, 'the Blackmoor being less sensible than the rest we made our Centry' (Neville, The Isle of Pines 64).

Moreover, using the slave-girl Philippa to breed the people of a new nation is a utilitarian misuse of her humanity. Philippa's materiality, in the context of the seventeenth-century English master-slave ideology, is denied when George represents her as 'less sensible,' but accentuated when he notices that she 'longed also for her' sexual 'share' after watching George's intercourse with the white females (67). Here, Spivak's criticism of 'an exclusive identification of woman with the reproductive or copulating body' is relevant: 'When the woman's body is used only as a metaphor for a nation (or anything else) feminists correctly object to the effacement of the materiality of that body' (Spivak 355).

Another evidence of racial prejudice in the Isle of Pines is the two uprisings caused by Philippa's descendents, John and Henry Phill, who ravish the white women of other tribes and are, consequently, executed. Further, the natives of Madagascar are depicted as 'very Unhospitable and Treacherous' (Neville, The Isle of Pines 84), East Indians as 'indifferently civil and ingenious' (83). Neville seems to have perfectly realized the 'racist humanism' of the British man who was born through 'creating slaves and monsters' out of the 'dirty niggers ... Jews and ... Arabs' (Sartre 22). The Phills' rebellion, violence, and surge into the 'forbidden quarters' can be interpreted in terms of a backlash against the violence of the British colonizing culture George transports to the Isle of Pines (Fanon 31).

\section{CONCLUSIONS}

Neville's pioneering amalgamation of colonial and racial discourses in the British genre of Utopia was induced by his quick perception of the underlying historico-political strata of the seventeenth century. Neville's attention to these nascent discourses opened a new chapter in the utopian literature of England in which the hidden agenda of the British imperial power could be approached more audaciously. Neville was one of the directors of the Virginia Company, relying on its profits to redress his 'battered financial position.' In the meantime, The Tempest was published the authorship of which has been attributed to Neville by W. D. Rubenstein and B. James in their The Truth Will Out (Rubenstein 28-9). Neville's supposed authorship - by no means a certain fact - of The Tempest may hint at a greater possibility: that of facing the other, the 'alien' in fictional terms. Neville might have produced aliens and scrutinized their relationship with human beings if he, like science fiction writers, had lived in the early twentieth century pulp era. After all, Neville was the first to direct British utopian architectonics toward anthropological aliens if not toward Martians.

\section{References}

[1] Aldridge A. O., "Polygamy in Early Fiction: Henry Neville and Denis Veiras," PMLA 65(4) (1950) 464-72.

[2] Bacon Francis, "Of Plantations," The Works of Francis Bacon, Baron of Verulam, Viscount St. Alban, and Lord High Chancellor of England Vol. 6, Ed. James

Spedding, R. L. Ellis, and D. D. Heath, 457-59. London: 1858. 
[3] Bhabha H. K., The Location of Culture, London: Routledge, 1994.

[4] Boesky Amy, "Nation, Miscegenation, Membering Utopia in Henry Neville's the Isle of Pines," Texas Studies in Literature and Language 37(2) (1995) 165-84.

[5] Bruce Susan, 'Introduction,' Three Early Modern Utopias, Ed. Susan Bruce, ix-xlii, Oxford: Oxford University Press, 1999.

[6] Fanon Frantz, The Wretched of the Earth, Trans. Constance Farrington, London: Penguin, 1976.

[7] Ford W. C., The Isle of Pines, 1668: An Essay in Bibliography, Boston: Club of Odd Volumes, 1920.

[8] Hardy N. W., “The Naughty Pines: Henry Neville's The Isle of Pines as Literary Hoax," PhD diss. University of McMaster, 1993.

[9] Heinlein R. A., Farmer in the Sky, New York: Ballantine, 1985.

[10] Hill C., The Experience of Defeat, Harmondsworth: Penguin, 1984.

[11] Hughes Derek, Versions of Blackness: Key Texts on Slavery from the Seventeenth Century, Cambridge: Cambridge University Press, 2007.

[12] Mahlberg Gaby, "Historical and Political Contexts of the Isle of Pines," Utopian Studies 17(1) (2006) 111-29.

[13] Mumford Lewis, The Myth of the Machine, New York: Harcourt, Brace \& World, 1967.

[14] Neville Henry, The Isle of Pines, In The Isle of Pines, 1668: An Essay in Bibliography, Ed. W. C. Ford, 49-87. Boston: Club of Odd Volumes, 1920.

[15] Neville Henry, Plato Redivivus, or A Dialogue Concerning Government. London: A Millar, 1763.

[16] Robbins Caroline, Ed. Two English Republican Tracts, Cambridge: Cambridge University Press, 1969.

[17] Rubenstein W. D., “Mystery Identities,” Today's History 55(11) (2005) 28-9.

[18] Sartre Jean-Paul, 'Preface,' In The Wretched of the Earth, By Frantz Fanon, Trans. Constance Farrington, 7-26. London: Penguin, 1976.

[19] Sherburn George, and Bond D. F., A Literary History of England: The Restoration and Eighteenth Century (1660-1789), Ed. A. C. Baugh, London: Routledge \& Kegan Paul, 2005.

[20] Sommerville J. P., “Absolutism and Royalism,” In The Cambridge History of Political Thought 1450-1700, Ed. J. H. Burns, 347-73. Cambridge: Cambridge University Press, 1991.

[21] Spivak G. C., “A Literary Representation of the Subaltern: A Woman's Text from the Third World," Other Worlds: Essays in Cultural Politics, 332-70. London: Routledge, 2006.

[22] Stillman P. G., "Monarchy, Disorder, and Politics in The Isle of Pines," Utopian Studies 17.1 (2006) 147-75. 
[23] Sullivan V. B., Machiavelli, Hobbes, and the Formation of a Liberal Republicanism in England, Cambridge: Cambridge University Press, 2004.

[24] Wiseman Susan, "Adam, the Father of all Flesh," Porno-Political Rhetoric and Political Theory in and After the English Civil War,' Special issue: Pamphlet Wars and Prose in the English Revolution Prose Studies 14 (1991) 134-57.

[25] Worden Blair, "English Republicanism," In The Cambridge History of Political Thought 1450-1700, Ed. J. H. Burns, 443-75. Cambridge: Cambridge University Press, 1991. 